\title{
Die Sinode van Emden: Bakermat van die Nederduitse Kerke in Suid-Afrika
}

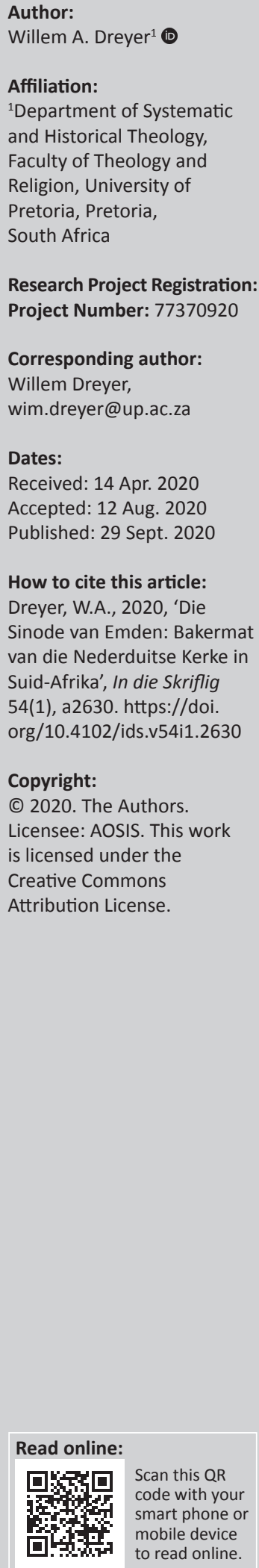

The Synod of Emden: Cradle of the Netherdutch churches of South Africa. The Synod of Emden, which took place from 04 to 13 October 1571 in the city of Emden, is of great importance to the reformed churches in South Africa. In this contribution the importance of the Synod is highlighted from three distinct perspectives: Firstly, from a historical perspective, the establishment and growth of Calvinism in the Netherlands up to the Synod of Emden is described. Secondly, from the perspective of church polity, some principles of church governance, which the Synod of Emden has formulated, are discussed. Thirdly, from the perspective of language history, some remarks are made on the use of Netherdutch by the Synod of Emden and the continued use of Nederduits in the name of the Dutch Reformed churches in South Africa. The early phase of Dutch reformation was characterised by great diversity. It was a time of fluid and changing reformation movements. Not only did the magisterial reformers such as Luther, Bullinger, Calvin, Beza and Zwingli influenced ecclesial transformation in the Netherlands, but the Humanism of Erasmus was well-known and influential; the work of the Brothers of Common Life and Geert Groote had much influence through the education of children; the Devotio Moderna and Imitatio Christi of á Kempis influenced a new type of spirituality; the older proto-reformation movements of Cornelis Hoen and Hinne Rode still had some influence; the Anabaptist movements of Melchior Hoffmann, Andreas Bodenstein von Karlstadt and Menno Simmons were active in many towns and communities. Despite this diversity, it is quite remarkable how the Dutch reformation was influenced fundamentally from the French-speaking south, especially by the theology of John Calvin. The unity between the Dutch and French churches was formalised by the Synod of Emden. The unity in confession and organisation was articulated expressis verbis in the second resolution of the Synod. The reformed churches in the Netherlands were persecuted and disorganised. War broke out between Spain and the Netherlands. There existed a great need for direction and structure. One of the remarkable features of the Reformation was its ability to rethink, reorganise and restructure the church. Instruments used in this process of reformation was not only the establishment of the sana doctrina, but also the use of assemblies such as synods and the publication of church orders which articulated the basic principles of reformed church governance. The importance of church orders as instruments of change is often under-valued. It was no different with the Synod of Emden. The Synod and the principles of church governance laid the foundation of the Dutch Reformed Church and gave direction to the reformation movement in the Netherlands, also in terms of language and the use of Nederduitsch, a term which is still used in the names of some reformed churches in South Africa.

Keywords: church history; church polity; Calvin; Calvinism;Netherlands; Luther; Bugenhagen; Northern Germany; Synod of Emden 1571; Netherdutch; Cape of Good Hope; First General Assembly Cape Town 1824.

\section{Inleidend}

Die Sinode van Emden het 450 jaar gelede plaasgevind. In 2021 sal daar in verskillende konferensies en publikasies hieraan aandag gegee word. Die Sinode, wat van 04 tot 13 Oktober 1571 in die Grote Kerk van Emden vergader het, is ook van besondere belang vir die Afrikaanse susterskerke. Die Afrikaanse susterskerke (Nederduitsch Hervormde Kerk van Afrika, Nederduitse Gereformeerde Kerk en die Gereformeerde Kerke van Suid-Afrika) het 'n gemeenskaplike geskiedenis vanaf die Sinode van Emden tot en met 1858-1859. Al drie hierdie kerke word doelbewus ingesluit wanneer die term Nederduitse kerke gebruik word soos later aangetoon sal word. In hierdie bydrae word die belangrikheid van die Sinode vanuit drie perspektiewe toegelig. 
Vanuit 'n kerkhistoriese perspektief was die Sinode van Emden die kulminasie van 'n moeisame proses van kerkhervorming in die Nederlande. In die eerste dekades van die kerkhervorming (tot 1550) het betreklik min in die Nederlandse kerk verander. Eers op 12 Julie 1562 het Calviniste die eerste keer in die openbaar vergader. Hulle het in die kerkhof in Boeschepe byeen gekom om te luister na 'n preek van Gelein Damman. Dit was die eerste van die sogenaamde 'hagenpreken' - eredienste en preke wat nie in kerke gehou is nie, maar buite in die veld of openbare plekke soos 'n kerkhof. Hierna het die Calvinisme vinnig veld gewen om uiteindelik deur die Sinode van Emden op 'n vaste koers geplaas te word. Die 'gereformeerde godsdiens' is van Nederland na die Kaap van Goeie Hoop verplant en deur die VOC in stand gehou en bevorder.

Vanuit 'n kerkregtelike perspektief is die Sinode van Emden van besondere belang vir die gereformeerde kerke in Suid-Afrika. Die Sinode het teologiese en kerkregtelike grondbeginsels neergelê wat die uitbreiding van die Calvinistiese kerkhervorming in Nederland en die westelike gedeeltes van Duitsland bestendig het. Die kerkregtelike beginsels wat in die notules ${ }^{1}$ van die Sinode van Emden opgeneem is, reflekteer steeds in die kerkordes van gereformeerde kerke in Suid-Afrika.

Vanuit 'n kultuurhistoriese perspektief, en na my mening van groot belang vir die geskiedenis van Afrikaans, is die besluite van die Sinode ten opsigte van taal. Die gebruik van moedertaal in die eredienste en kategese, asook die spesifieke verwysing na Nederduits in die handelinge van die Sinode, is interessant en belangrik.

In hierdie bydrae word die voorgeskiedenis en enkele besluite van die Sinode van Emden aan die hand van bogenoemde drie perspektiewe toegelig.

\section{Kerkhistoriese perspektief: Vroeë kerkhervorming in Nederland en Oos-Friesland}

Die vroeë fase van die Nederlandse kerkhervorming vertoon groot diversiteit. Dit was 'n vloeibare, veranderende en diverse beweging. Behalwe die invloed van die 'groot' kerkhervormers soos Luther, Melanchthon, Zwingli, Bullinger en Calvyn in Nederland, was die Humanisme van Erasmus goed bekend en invloedryk. Daar was ook die denke van Geert Groote en die Devotio Moderna; die Nederlandse proto-reformasie van Cornelis Hoen (oorlede 1524) en Hinne Rode (oorlede 1537) wat steeds invloed uitgeoefen het; Anabaptiste soos Melchior Hoffmann, Andreas Bodenstein von Karlstadt; en Menno Simmons se volgelinge wat in verskillende stede aktief besig was om geloofsgemeenskappe te vestig.

1.Die notules van die Sinode van Emden in Nederduits, Latyn, Duits en Frans is te vind in Goeters (1971). In hierdie bydrae word na die Acta van die Sinode van Emden verwys as 'Goeters 1971'.
Die diversiteit op kerklike terrein ${ }^{2}$ het tot in die sewentiende eeu en daarna voortgeduur, onder meer in die stryd tussen die Remonstrante en Contra-Remonstrante wat daartoe gelei het dat die Sinode van Dordt (1618-1619) byeengeroep is om te besin oor die uitverkiesingsleer. Die diversiteit was nie net in die suide van Nederland opsigtelik nie, maar het ook oorgespoel na die noorde van Nederland, veral as gevolg van die groot getal vlugtelinge vanuit die suide wat hulle in die omgewing van Emden gevestig het.

Ten spyte van die diversiteit, is dit opvallend dat die Nederlandse kerkhervorming hoofsaaklik vanuit die Franssprekende suide beïnvloed is, en veral deur die teologie van Johannes Calvyn. Calvyn is in 1509 as 'Jehan Cauvin' (kyk Dreyer 2010) in Noyon gebore - 'n dorpie in Pikardië 115 kilometer noord van Parys en 130 kilometer suid van die Belgiese grens. Die suidelike gedeeltes van Nederland (tans België) was Franssprekend en het aan Frankryk gegrens. Die verdeling tussen Nederland, België en Luxemburg is 'n redelik moderne verskynsel en die gevolg van die Belgiese Revolusie (1830-1839). Daarom is dit vanselfsprekend dat die Frans-Calvinistiese kerkhervorming van Frankryk na België (die suide van Nederland) sou oorspoel.

Die affiniteit van die vroeë Nederlandse kerkhervormers vir die Franse denke was nie net die gevolg van geografiese taalkundige - en kulturele verbintenisse nie. Heelwat Nederlandse predikante het in Genève, onder leiding van Calvyn of Beza, hulle teologiese opleiding ontvang. Die Frans-Calvinistiese invloed vanuit Genève en Parys was baie kragtiger as die Duits-Lutherse invloed vanuit Wittenberg.

Die getal lidmate van die Calvinistiese gemeente in Emden is voortdurend deur vlugtelinge uit Frankryk, Nederland, Switserland, Duitsland, Engeland en Pole aangevul wat ter wille van hulle persoonlike veiligheid aan die Noordsee 'n heenkome gevind het. Na 1565 was daar 'n skerp toename in die vervolging van hervormgesindes en moes hulle vlug na veilige gebiede. Meer as 100000 Protestante het in sogenaamde 'vlugtelingsgemeentes' byeengekom. Na die uitbreek van die oorlog tussen Spanje en Nederland in 1566, het die getal vlugtelinge vinniger gegroei en het derduisende Franssprekende vlugtelinge uit Frankryk en die suide van Nederland hulle rondom Emden gevestig. Gevolglik het die invloed van die Calvinistiese kerkhervorming toenemend sterker geword (Schilling \& Schreiber 1989:xi).

Die eenheid en geloofsband tussen die Nederlandse en Franse kerke is geformaliseer tydens die Sinode van Emden. Die tweede besluit van die Sinode van Emden lui soos volg (aangehaal in Pont 1981):

$[O] \mathrm{m}$ de eendrachtigheydt in de Leere tusschen de Nederlandtsche Kerken te bewijsen, heeft het den Broederen goedgedacht de belijdinge des Gheloofs der Nederlandtsche Kerken te onderschrijven, insgelijcx ook de Belijdinge der Kerken in Vranckrijk te ondertekenen ... (p. 94)

2.Vir 'n deeglike oorsig van die verskillende hervormingsbewegings in Nederland gedurende die vyftiende en sestiende eeu, kyk Knappert (1924). 
Die Sinode van Emden aanvaar daarmee die Nederlandse Geloofsbelydenis sowel as die Franse Geloofsbelydenis as bindend en die ware opsomming van die Christelike geloof. Calvyn het 'n groot aandeel gehad in die opstel van die Franse Geloofsbelydenis wat in 1559 deur die Sinode van Parys hersien en aanvaar is. Guido de Bres, afkomstig uit Franssprekende Nederland (België), het in 1561 die Franse Geloofsbelydenis verwerk en dit het bekend geword as die Confessio Belgica of Nederlandse Geloofsbelydenis. Hierdie eerste besluit van die Sinode van Emden het die band met die Franse kerk en die invloed van Calvyn vasgelê.

Daarteenoor was die invloed van Luther in Emden beperk ten spyte van heelwat stede aan die Noordsee en Baltiese See wat tot die Lutherse kerkhervorming oorgegaan het. Lübeck, die belangrikste stad in die Hansa Handelsverbond, het reeds in 1531 onder leiding van Johannes Bugenhagen, Luther se medewerker en predikant in Wittenberg, deel van die Lutherse kerkhervorming geword.

Johannes Bugenhagen (1485-1558) was 'n boorling van Lübeck en sy moedertaal was Nederduits. Hy het besondere moeite gedoen om die gebruik van Nederduits te bevorder (kyk in hierdie verband Dreyer 2017). Sy bynaam was die 'Apostel van die Noorde', veral as gevolg van sy herorganisasie van die kerke in Noord-Duitsland en die Skandinawiese lande. Bugenhagen het ook met Luther saamgewerk ten opsigte van Bybelvertaling. Soos wat Luther se Hoogduitse Bybelvertaling gevorder het, het Bugenhagen nie net gehelp met die Hoogduitse vertaling nie, maar ook 'n ooreenstemmende vertaling in Nederduits gedoen.

In Oos-Friesland (insluitend Emden) is die Lutherse invloed primêr deur die owerheid bevorder. Oos-Friesland was 'n hertogdom wat vir byna 300 jaar (1464-1744) deur die adellike familie, Cirksena, regeer is. Belangrik vir die geskiedenis van die Kerkhervorming, was Hertog Enno II van Oos-Friesland (1505-1540). Na die dood van sy vader, hertog Edzard I die Grote, het Enno II in 1528 die hertog van Oos-Friesland geword. Hy was 'n oortuigde Lutheraan en het alles gedoen om die Lutherse denke te bevorder. Hy het verskeie aanvalle teen Roomse kloosters gelei en Roomse eiendomme gekonfiskeer. Hy is op die jeugdige ouderdom van 35 oorlede en is deur sy vrou, Anna van Oldenburg, as regent opgevolg. Sy het tot 1561 regeer, waarna haar twee seuns, Johan II en Edzard II, gesamentlik regeer het tot met die dood van Johan II in 1591. Daarna het Edzard II alleen regeer tot met sy dood in 1599 .

Soos gebruiklik in die Lutherse kerkhervorming het hertog Enno II, as Christelike owerheid, 'n superintendent aangestel wat vir die voortgang van die Lutherse kerkhervorming in Oos-Friesland verantwoordelik sou wees (Jürgens 1999:5; Schilling \& Schreiber 1989:xii). Die persoon wat hy aangestel het, was Johannes á Lasco, 'n skatryk Poolse edelman. Sy oorspronklike Poolse naam was Jan Laski. Laski se vader en oom was invloedryke politieke leiers in Pole. Sy oom het, onder andere, as rykskanselier aan die koninklike hof gedien (Jürgens 1999:16).

Laski het die posisie van superintendent van 1544 tot 1549 beklee. Sy posisie is bemoeilik met die groeiende invloed van die Calvinisme in Oos-Friesland, maar dit het nie verhoed dat hy 'n belangrike bydrae tot die Kerkhervorming in Oos-Friesland en Emden gemaak het nie. Naas Oos-Friesland het Laski ook in Hongarye, Engeland (as superintendent van Londen), Denemarke, Duitsland (Frankfurt) en Pole 'n bepaalde invloed uitgeoefen. Laski was 'n selfstandige teoloog, maar is ook deur Luther, Zwingli en Bullinger beïnvloed. Hoewel hy hervormgesind was, het sy teologie 'n moralistiese inslag gehad waarin die leer van die goeie werke 'n bepaalde plek behou het. Dit kom na vore in die streng kerklike dissipline wat hy toegepas het. Laski het sy fortuin beskikbaar gestel vir die opbou van die reformatoriese kerke, onder meer die vestiging van 'n biblioteek. 'n Gedeelte van die boekery word steeds in die biblioteek van die Johannes á Lasco Instituut in Emden bewaar.

Soos reeds gemeld, het verskillende godsdienstige groeperings in Emden 'n heenkome gevind. Die kerklike diversiteit het tot konflik tussen die Lutherse hertog en die kerkraad van Emden gelei. Een voorbeeld hiervan was die besluit wat die kerkraad ${ }^{3}$ op 21 Februarie 1575 geneem het. Tydens die vergadering is besluit om 'n spesiale biddag te hou vir die instandhouding van die suiwer Woord van God in al die streke en kerke (sien die Nederduits hieronder). ${ }^{4}$ Die oënskynlike solidariteit met ander geloofsgemeenskappe in ander streke wat in hierdie besluit verwoord word, het tot konflik met die Luthersgesinde hertog gelei.

Later is hierdie spanning op die spits gedryf met die Emdense Revolusie (1595), wat in die Grote Kerk in Emden van stapel gestuur is na 'n inspirerende preek van ds. Menno Alting. Die redes vir die mense se verset teen die hertog was enersyds godsdienstig van aard, en andersyds die gevolg van onredelike belastings wat hy gehef het. $\mathrm{Na}$ 'n uitgerekte stryd en oorlog is Emden losgemaak van die hertogdom en het dit as vrystad onder die Nederlandse Staten-Generaal geressorteer.

Die eerste notule van die Kerkraad van Emden is 16 Julie 1557 gedateer (Schilling \& Schreiber 1989:1). Dit kan as die terminus a quo van die Calvinistiese kerkhervorming in Emden beskou word. Opvallend genoeg was armesorg en barmhartigheidsdiens die eerste sake waaraan die kerkraad aandag gegee het. Die diakens (tipies Calvinisties) is opgeroep om verslag te lewer oor hulle werk - waarskynlik omdat die groot getal Protestantse vlugtelinge in armoede geleef het en in die voorafgaande gure winterweer talle ontberings moes verduur.

3.Vir die notules van die Kerkraad van Emden

4.Die besluit in die oorspronklike Nederduits lui soos volg: 'Is ock besloten, dat thokumstige sondach [over] achte dage ein gemen vastelunde bedeldach sal geholden werden ... um ein truven dener unde generale underholdinge des rheinen Wortes overall' (Schilling \& Schreiber 1989:558). 
Teen 1570, in net meer as 10 jaar en veral onder invloed van ds. Menso Alting, was Calvyn se teologiese denke reeds goed bekend. Menso Alting is in 1541 in Eelde (in Drente) gebore en in 1612 in Emden oorlede. Alting het as jong seun by sy oom in Groningen gaan woon, waar hy ook skoolgegaan het. In Groningen maak hy op jong ouderdom met die Humanisme van Erasmus en die Groningen-reformasiebeweging kennis (Voss 2012:13). Alting het in Keulen studeer en daarna (1565) aan die Universiteit van Heidelberg. Hy arriveer in Heidelberg slegs twee jaar na die Heidelbergse Kategismus (1563) voltooi is en in 'n tyd van spanning en konflik tussen die Calviniste en Lutherane oor die inhoud van die Heidelbergse Kategismus (kyk in hierdie verband Dreyer 2014). Dit is dus vanselfsprekend dat Alting die Heidelbergse Kategismus geken het en gekies het om homself aan die kant van die Calviniste te skaar. Alting het verskeie gemeentes in Drente, Heidelberg (ook as hofprediker) en Emden bedien. Vanaf die heel begin was die Heidelbergse Kategismus besonder invloedryk in Emden - nie net in die kategese en prediking nie, maar ook in die vorming van 'n bepaalde teologiese milieu.

\section{Kerkregtelike perspektief: Die Sinode van Emden}

Die gereformeerde gemeentes in Nederland was voor die Sinode van Emden verstrooid en gedisorganiseer. Daar was 'n dringende behoefte aan rigting, struktuur en organisasie. Een van die kenmerke van die hervormingsbeweging was die vermoë om gemeentes tot 'n groter eenheid saam te snoer en struktuur te skep. Dit is gedoen deur besluite van sinodale vergaderings, asook die opstel en implementering van kerkordes. Een van die belangrike instrumente waardeur kerkhervorming bevorder is, was kerkordes. In die navorsing oor die sestiende-eeuse Kerkhervorming word die rol van kerkordes dikwels onderskat. Die kerkordende werk van die Sinode van Emden het die 'fondamente vir die Nederlandse hervormde kerk gelê lank voordat dit 'n uitgemaakte saak was dat die Hervorming in Nederland sou seëvier' (Pont 1981:92).

Die organisasie van die kerk het tydens die Konvent van Wesel (1568) begin, waar Datheen, Marnix van St. Aldegonde en Zuylen van Nyevelt die leiding geneem het. Talle van die Protestantse vlugtelingsgemeentes was daar verteenwoordig (Pont 1994:65). Die Konvent van Wesel het ook voorbereidende werk vir 'n volwaardige sinode gedoen. Marnix van St. Aldegonde het hom vir 'n volwaardige nasionale sinode beywer. Daarin is hy deur prins Willem van Oranje ondersteun. Die droom van 'n nasionale sinode wat die kerk in Nederland op vaste bane kon lei, is verwesenlik by die Sinode van Emden (Pont 1981:95).

Dit het drie jaar later, van 04 tot 13 Oktober 1571, in Emden plaasgevind. Emden is as vergaderplek gekies omdat dit betreklik veilig was om daarheen te reis en daar te vergader. Slegs 22 predikante en vyf ouderlinge het sitting geneem
(Goeters 1971:7). Caspar Heidanus, predikant in Frankenthal (Pont 1994:67) is as voorsitter verkies en Johannes Polyander as skriba (Pont 1981:95).

Ouer kerkregkenners soos Rutgers het bedenkings gehad of die Sinode van Emden die status as 'n eerste nasionale sinode in Nederland moet verkry (kyk Pont 1981:92). Hierdie argument word op die beperkte getal afgevaardigdes gebaseer wat nie verteenwoordigend van al die Nederlandse provinsies was nie. Die predikante wat teenwoordig was, was almal uit Oos-Friesland, Duitsland en die sogenaamde 'gemeentes onder die kruis' of vlugtelinggemeentes afkomstig. Daarteenoor argumenteer Haitjema (kyk Pont 1981:92) dat dit wel die eerste nasionale sinode van die Nederlandse kerk is op grond van die inhoud en omvang van die werk wat die sinode in terme van kerklike organisasie vir die hele Nederland gedoen het.

Hier moet in gedagte gehou word dat dit 'n buitengewone tyd was omdat oorlog tussen Nederland en Spanje gewoed het. Die Tagtigjarige Oorlog het van 1568 tot 1648 geduur. Die provinsies Holland en Zeeland is eers in 1573, na die Sinode van Emden, uit die mag van die Spanjaarde bevry. Dit is dus begryplik dat afvaardigings na sinodes nie volledige verteenwoordiging sou vertoon nie. Pont (1981:93) kom tot die gevolgtrekking dat die Sinode van Emden as die eerste Nederlandse sinode beskou moet word wat die grondlyne vir verdere hervorming en uitbreiding getrek het.

Die bedoeling van die Sinode van Emden was die formalisering van die 'Nederlandtschen kercken, die onder 't cruys sitten ende der gener, die door Duytsch - ende Oost Vryeslandt verstroyt sijn' (Goeters 1971:14). Die wye omvang van die Sinode se werksaamhede blyk uit besluite wat nie net op die gemeentes in Nederland gerig was nie, maar ook op die vlugtelinggemeentes in Engeland, Duitsland, Frankryk en België, hoewel daar nie van oral afgevaardigdes teenwoordig was nie.

Die wye omvang van die Sinode van Emden se organiserende werk word ook sigbaar in die klassikale indeling wat die Sinode gemaak het. Vanaf Artikel 7 (Goeters 1971:16 e.v.) word dit duidelik dat Duitse, Engelse, Oos-Friese, Vlaamse (so ver as Brussel) en Waalse (Franssprekende) gemeentes deur die sinodale besluite geraak is. Benewens Nederlandse stede, word stede soos Heidelberg, Frankfurt, Keulen, Brussel en verskeie ander by die klassikale indeling betrek. Dit dui daarop dat die Sinode van Emden kerkregtelik en organisatories 'n belangrike bydrae tot die ontwikkeling en vestiging van die gereformeerde geloof in Nederland en die aangrensende gebiede gelewer het.

Die effek van die Sinode van Emden kan met dié van die Sinode van Parys (1559) op die gereformeerde kerk in Frankryk vergelyk word (Goeters 1971:7). Opvallend is die invloed van die Franse sinodes op die Sinode van Emden. Dit is waarskynlik dat die afgevaardigdes by Emden 'n afskrif van die Acta van die Sinode van Parys (1559) ter tafel gehad het. 
Die Sinode van Emden het nie formeel 'n kerkorde opgestel nie, maar talle van die besluite was bepalend vir toekomstige kerkordes. Die sinodes van Dordrecht (1574 sowel as 1619) het die kerkregtelike beginsels wat Emden verwoord het, gesistematiseer en onder bepaalde opskrifte (byvoorbeeld ampte; vergaderings van die ampte; bediening van sakramente) in kerkordes ingeskryf (kyk Pont 1981:93).

Die Sinode van Emden het 53 formele besluite geneem (kyk Goeters 1971:14-54). Enkele voorbeelde van die kerkregtelike beginsels wat in die besluite van die Sinode van Emden verwoord is, word kortliks genoem:

- Die nie-hiërargiese beginsel bepaal dat geen kerk oor 'n ander kerk, geen vergadering oor ander vergadering en geen ampsdraer oor ' $n$ ander ampsdraer sal heers nie. Dit moes dien as teenvoeter vir die Rooms-Katolieke hiërargie met die pous as hoof en vicarius Christi. Hierdie formulering is tipies Calvinisties in oorsprong en bedoeling. Dit sluit ook aan by Artikel 31 van die Nederlandse Geloofsbelydenis waar bely word dat Jesus Christus die enigste Hoof en Heer van die kerk is. Alle ampte en vergaderings van die ampte is onderworpe aan die heerskappy van Christus wat deur sy Woord en Gees oor die kerk regeer.

- Ten opsigte van die ampte word daar op die tipies Frans-Calvinistiese wyse tussen die predikant, ouderling en diaken onderskei. Die geordende predikant was vir die verkondiging van die evangelie en die bediening van die sakramente verantwoordelik, terwyl die ouderling vir opsig en dissipline verantwoordelik was. In die notules van die kerkraad is dit opvallend dat die ouderlinge weekliks mense oor sake soos owerspel, dronkenskap op straat en ander openbare sondes vermaan en bestraf het.

- Die primêre vergadering van die ampte, wat in gehoorsaamheid aan Christus en die Woord oor die kerk moet regeer en opsig uitoefen, is die kerkraad en nie die sinode nie. Die Sinode van Emden (besluit 6) noem die kerkraad die 'konsistorie'. By Emden (soos in die Franse gemeentes) was die diakens nog deel van die kerkraadsvergadering, maar latere kerkordes het die kerkregering in die hande van die ouderlinge geplaas wat beteken het dat diakens nie meer op die kerkraad sitting geneem het nie, behalwe in baie klein gemeentes met min ouderlinge.

- Die Sinode van Emden het voorsiening gemaak vir lezers (kyk Pont:1981:98-99) in gevalle waar daar nie predikante beskikbaar was nie. Die funksie van die lezer was om in die erediens voor te gaan en preke voor te lees. Dit is interessant dat die praktyk van die voorleser vandag nog in die Nederduitsch Hervormde Kerk van Afrika bestaan - hoewel met minder verantwoordelikhede.

In die volgende gedeelte sal enkele opmerkings oor die belydenis en die kategese gemaak word.

\section{Kultuurhistoriese perspektief: Die gebruik van Nederduits}

Dit is nie vreemd dat ons verskeie verwysings na 'Nederduits' in die Acta van die Sinode van die Emden kry nie. Prediking, kategese en onderrig in die mense se moedertaal was een van die hoekstene van die Kerkhervorming en 'n belangrike deel van liturgiese transformasie gedurende die sestiende eeu. Die bediening van die sakramente, die prediking en sang is nie meer in Latyn gedoen nie, maar in die plaaslike mense se taal. Dit is opmerklik dat moedertaal ook vir die Sinode van Emden 'n belangrike saak was - in besonder Nederduits.

Nederduits was vir lank die algemene omgangstaal in die Hansestede aan die Noordsee (Becker-Cantario 1988:63-72). In Suid-Afrika is daar twee kerke wat 'Nederduits' as deel van hulle naam het, te wete die Nederduitse Gereformeerde Kerk en die Nederduitsch Hervormde Kerk van Afrika. Ter wille van die historiese belang van die term Nederduits word hier enkele opmerkings oor Nederduits as taal gemaak.

Nederduits is die taal wat in die noorde van Nederland en Duitsland gepraat is met enkele streeksvariante. Die verskillende Nederduitse variante word noord van die Benrathse en Uerdingense isoglosse gepraat, terwyl die hedendaagse Standaardduits (Hoogduits) meer na die suide ontwikkel het. Nederduits, Fries en Oudengels het vanuit Oudsaksies ontwikkel en versprei as gevolg van die migrasie van Saksers deur die noorde van Europa en Engeland. Tussen die vyfde en elfde eeu na Christus het Anglo-Saksiese groepe hulle oor groot dele van Engeland gevestig. Die Saksers se migrasie na Engeland het verminder nadat die Noorse besetting van Engeland begin het. Hierdie gemeenskaplike verbintenis met Oudsaksies is in Engels en Afrikaans sigbaar, byvoorbeeld in woorde soos 'water', terwyl in Hoogduits, die konsonant 'n klankverskuiwing na 'Wasser' ondergaan het.

Deur die loop van die sewentiende eeu is Nederduits stelselmatig as lingua franca van die noordelike streke verdring. Hoogduits, veral onder invloed van die Lutherse kerkhervorming en Bybelvertaling, het 'n al groter invloed uitgeoefen en is toenemend as administratiewe en regstaal gebruik. Hoogduits het geografies en chronologies van die suide na die noorde versprei. In die verre noorde, soos Holstein, het Nederduits nog lank as algemene omgangstaal bly voortleef.

In skole is Nederduits eers later deur Hoogduits as medium van onderrig vervang. In die akademiese omgewing (universiteite) is Latyn steeds gebruik. Teen 1700 is Nederduits relatief min as geskrewe taal gebruik, maar die middelklas (boere en arbeiders) het lank nadat Hoogduits die amptelike taal geword het, voortgegaan om Nederduits as algemene omgangstaal te gebruik. Geskoolde mense met 'n akademiese agtergrond soos predikante, regsgeleerdes, dokters, staatsamptenare en landhere was dikwels Nederduits en Hoogduits magtig. 
Vanweë die verspreiding van Hoogduits, is daar toenemend op Nederduits neergesien en is dit as minderwaardig beskou - as 'kombuistaal' wat veral deur die werkersklas gepraat word. Die hooggeleerde prof. Chytraeus van Rostock Universiteit het in 1582, kort na die Sinode van Emden, Nederduits as 'horrida, inculta et imperfecta' beskryf (Becker-Cantario 1988:64). Ten spyte van hierdie negatiewe ingesteldheid teenoor Nederduits is dit nog lank in skole en kerke gebruik. Die rede hiervoor is vanselfsprekend: Ongeskoolde mense het byna uitsluitlik Nederduits gepraat en in die kerke en skole is die mense se moedertaal gebruik (kyk in hierdie verband na voorbeelde in Becker-Cantario 1988).

'n Merkwaardige verwysing na 'Nederduitsch' vind ons in Artikel 5 van die Acta van die Sinode (Goeters 1971) waar daar na die Geneefse Kategismus en die Heidelbergse Kategismus verwys word:

De broders hebben geacht, dat men in den ghemeynten der Francoischer spraecke die forme die Geneefschen catechismi ende in den ghemeynten der Nederduitschen spraecke die forme des Heidelbercschen behoort te gebruicken. (p. 16)

Ter wille van die eenheid van die kerk is die Franssprekende gemeentes toegelaat om die Geneefse Kategismus in die kategetiese onderrig te gebruik. In die gemeentes waar Nederduits as voertaal gebruik is, moes die Heidelbergse Kategismus gebruik word. Ander kerke mag ook hulle eie kategismusse gebruik, solank dit in ooreenstemming met die Woord van God is. Daar word uitdruklik besluit om nie die gebruik van één kategismus af te dwing nie. Opvallend is dat die Heidelbergse Kategismus spesifiek aan Nederduitsch verbind word.

Taal het ook ter sprake gekom toe daar geantwoord is op die 'broeders uit Keulen' se vraag oor 'correcte oversettinghe des bibels in Nederduitsche spraecke' (Goeters 1971:56). Die gevoel van die Sinode was dat ' $n$ finale besluit oor die vertaling van die Bybel in Nederduits eers uitgestel moes word. Die vraag oor 'n korrekte Bybelvertaling moet verstaan word teen die agtergrond van die reeds bestaande Delftse (1477), Liesveldtse (1526), Biestkense (1560) en Deux-Aes vertalings (1562) wat nie aan die verwagtings voldoen het nie. Tegelykertyd was daar ook reeds die Nederduitse Bybelvertaling van Bugenhagen.

Goedkeuring vir 'n Nederduitse vertaling is eers deur die Sinode van Dordt (1618-1619) gegee. Op die titelblad van die eerste Statenbijbel wat in 1637 verskyn het, word dit duidelik gestel dat die vertaling 'uyt de oorspronckelijke tale in onse Nederlandtsche tale getrouwelijk overgeset' is. Die 'Nederlandse tale' waarna verwys word, het beteken dat elemente uit verskillende streekstale (onder meer Nedersaksies/Nederduits) opgeneem is. Die Statevertaling het tot die standaardisering van Nederlands en die ontwikkeling van moderne Nederlands bygedra net soos Luther se Duitse vertaling die vorming van moderne Duits bevorder het.
Met die emigrasie van duisende Nederduitsers na die Kaap van Goeie Hoop is die term Nederduitsch algemeen as taalaanduiding gebruik (Den Besten 2012:102). Die gebruik van Nederduitsch het voortgeduur tot na die Groot Trek, hoewel 'Nederlands' en 'Hollands' dit stelselmatig verdring het. Met die stigting van die Genootskap van Regte Afrikaners in 1875 en die invloed van die Eerste Taalbeweging, word die spreektaal toenemend as 'Afrikaans' aangedui.

\section{Enkele opmerkings oor die eerste Nederduitse sinode in Kaapstad (1824)}

Ter wille van die Suid-Afrikaanse kerkgeskiedenis word ook enkele opmerkings oor die gebruik van die term Nederduits in die Suid-Afrikaanse konteks gemaak. Dit was in Nederland sowel as die Kaap algemene gebruik om na die taal wat gepraat word as 'Nederduits' te verwys. In 1793 het daar byvoorbeeld 'n standaardwoordeboek onder die titel Dictionaire Francois-Hollandois Woordenboek NederduytschFransch verskyn. Nie in die Franse of Nederduitse titel word 'Nederlands' as taalaanduiding gebruik nie. In 1846 verskyn die Nieuw Fransch-Nederduitsch en Nederduitsch-Fransch Woordenboek, opgestel deur S.J.M. Moock (1846).

Tweehonderd jaar nadat die Nasionale Sinode van Dordrecht (1618-1619) die Dordtse Kerkorde goedgekeur het, het die Nasionale Sinode van Den Haag op 03 Julie 1816 vergader om 'n nuwe Algemeen Reglement goed te keur, onder die titel Algemeen Reglement voor het bestuur der Hervormde Kerk in het Koningrijk der Nederlanden (kyk Nel 2019). Nadat die Algemeen Reglement in 1816 aanvaar is, het die kerk toenemend as die Nederlands Hervormde Kerk bekend gestaan, hoewel die 'naam' nie só in die Algemeen Reglement verskyn nie. In die Algemeen Reglement van 1816 word bloot na die 'Hervormde Kerk' verwys (kyk teks in Nel 2019:199 e.v.). 'Nederlands' word in die Algemeen Reglement van 1816 net as geografiese aanduiding gebruik en nie as ' $n$ taalkundige aanduiding nie.

Tydens die Napoleontiese oorloë het Engeland die Kaap van Goeie Hoop in besit geneem. Dit was om as teenvoeter te dien vir die eskadron Franse fregatte wat in Madagaskar gestasioneer was. Nadat Napoleon die eerste keer verslaan is, is die Kaap aan Nederland teruggegee en het die Bataafse parlement Janssens en De Mist gestuur om sake te orden. De Mist het 'n kerkorde opgestel wat voorsien het dat daar 'n selfstandige sinode aan die Kaap kon konstitueer - in effek 'n selfstandige kerk. Nadat Napoleon ontsnap het, het Engeland die Kaap vir 'n tweede keer (1806) beset. Dit het die implementering van De Mist se kerkorde gestuit, veral ten opsigte van 'n selfstandige sinode. Dit sou eers in 1824 realiseer. Die gereformeerde gemeentes in die Kaap van Goeie Hoop het in hierdie tyd basies selfstandig gefunksioneer - losgeslaan van die moederkerk in Nederland, afgesonderd van mekaar en met een gesamentlike raakpunt: die kantoor van die goewerneur in Kaapstad. 
Tydens die eerste Algemene Kerkvergadering wat in 1824 in Kaapstad sitting geneem het, het die gereformeerde gemeentes aan die Kaap vir die eerste keer selfstandigheid verkry. Met die Algemene Kerkvergadering van 1824 kom daar formeel en kerkordelik, met toestemming van die owerheid, 'n selfstandige gereformeerde kerk in Suid-Afrika tot stand. In die agtiende eeu het die Kaapse gemeentes gewoon onder die Klassis van Amsterdam en die Sinode van Noord-Holland geressorteer. Dit is dus histories en kerkordelik foutief om die ontstaan van die Afrikaanse kerke na die koms van Jan van Riebeeck terug te voer soos dikwels beweer word. Tot en met 1824 was die Kaapse gemeentes de iure deel van die Nederlandse kerk.

Die eerste taak wat die Algemene Kerkvergadering in 1824 moes afhandel, was om 'n kerkorde op te stel waardeur die selfstandige kerk sou konstitueer. Die Kaapse kerk het die Nederlandse Algemeen Reglement van 1816 as voorbeeld gebruik en nie die Dordtse Kerkorde van 1619 nie. Die titel van die 1824 Kaapse kerkorde was Algemeen Reglement voor het bestuur der Nederduitsche Hervormde Kerk, in Zuid-Afrika, ontworpen in de Algemene Kerkvergadering, gehouden binnen de Kaapstad, op den 2 November, en volgende dagen van het jaar 1824 (kyk teks in Pont 1991:216). Die Reglement het van krag gebly tot na die Groot Trek in 1842.

Die Kaapse kerk het besluit om die 1824-Reglement volledig te hersien. Die hersiening is tydens die sinode van 1842 afgehandel. Een van die veranderings wat aangebring is, was verandering van die naam van die kerk na Nederduitsch Gereformeerd. Die besluit is geneem ten spyte van besware wat sommige predikante (o.a. Abraham Faure) tydens die sinode van 1842 teen 'n naamsverandering geopper het. Dit is dus opvallend dat die Kaapse sinode steeds van mening was dat 'Nederduits' deel van die naam van die kerk moes wees.

In Nederland het die Algemeen Reglement die klem op Nederland as geografiese gebied laat val - waarskynlik ter bevordering van groter sosiale kohesie en eenheid - nadat die Napoleontiese oorheersing van Nederland tot 'n einde gekom het. Anders as die Nederlandse Algemeen Reglement, het die Kaapse kerk die taalaanduiding 'Nederduitsch' in die naam van die kerk bygevoeg in kombinasie met 'Hervormd' en 'Gereformeerd'. Die konsekwente handhawing van 'Nederduits' in die naam van die kerk, moet, na my mening, verstaan word teen die agtergrond van die verengelsingsbeleid van die Britse goewerneurs en die aanstelling van Skotse predikante in 'n poging om die kerk (soos skole en die staatsdiens) te verengels. Soos vir die vadere van Emden, was die Kaapse kerk oortuig dat dit belangrik is om die evangelie in jou moedertaal te hoor - dus in Nederduits. Hoewel Nederduits in Suid-Afrika verdwyn het, is die kwessie van taal steeds belangrik. Die behoud van die term Nederduits in sommige kerke se naam mag argaïes en selfs uitgediend wees, maar in 'n sekere sin slaan dit die brug na die Sinode van Emden - 'n geskiedenis van 450 jaar gelede.

\section{Slotopmerkings}

In 2021 herdenk gereformeerde kerke die Sinode van Emden wêreldwyd. Dit op sigself is belangrik. Daar is ook aangetoon dat die Sinode van Emden histories en kerkregtelik van groot belang is vir die Afrikaanse susterskerke.

Die geskiedenis van die Kerkhervorming in die noorde van Duitsland en Nederland, in Oos-Friesland en Holstein, is nie meer so goed bekend in Suid-Afrika nie. Ek vind dit om verskillende redes jammer. Dit verarm nie net ons kennis van die Kerkhervorming en die gereformeerde kerkgeskiedenis nie, maar dit is ook 'n verlies vir die Afrikaanse kultuurgeskiedenis. 'n Beduidende deel van Afrikaanssprekende families se stamouers het vanuit die noorde van Europa geëmigreer en vanaf 1652 aan die Kaap gevestig. 'n Mens hoef maar net deur die begraafplase van 'n stad soos Emden te loop om te sien hoeveel 'Afrikaanse' vanne op die grafstene staan.

As ons na die diepste wortels van die gereformeerde kerke in Suid-Afrika soek, sou dit loon om meer aandag aan die Kerkhervorming in Noord-Europa te gee. Dit was die filter waardeur die Calvinisme nie net in Nederland gevestig het nie, maar ook in Suid-Afrika.

\section{Erkenning Mededingende belange}

Die outeur verklaar dat daar geen finansiële of persoonlike verbintenis is met enige party wat hom nadelig kon beïnvloed in die skryf van hierdie artikel nie.

\section{Outersbydrae}

W.A.D. was die enigste outeur betrokke by die skryf van die artikel.

\section{Etiese oorweging}

Hierdie artikel volg alle etiese standaarde vir navorsing.

\section{Befondsing}

Hierdie navorsing het geen spesifieke toekenning ontvang van enige befondsingsagentskap in die openbare, kommersiële of nie-winsgewende sektore.

\section{Data beskikbaarheidsverklaring}

Die outeur bevestig dat die data wat die bevindinge van hierdie studie ondersteun, beskikbaar is in die artikel.

\section{Vrywaring}

Die sienings en menings wat in hierdie artikel uitgedruk word, is dié van die outeur en weerspieël nie noodwendig die amptelike beleid of posisie van enige geaffilieerde agentskap van die outeurs nie. 


\section{Literatuurverwysings}

Den Besten, H., 2012, Roots of Afrikaans. Selected writings of Hans den Besten [Creole Language Library 44], in T. van der Wouden (ed.), John Benjamin Publishing Co. Amsterdam.

Dreyer, W.A., 2010, 'From Noyon to Geneva', In die Skriflig 44, suppl. ser. 3, 1-22.

Dreyer, W.A., 2014, 'The Heidelberg Catechism: A 16th century quest for unity', HTS Teologiese Studies/Theological Studies 70(1), Art. \#2092, 5 pages. https://doi. org/10.4102/hts.v70i1.2092

Dreyer, W.A., 2017, 'Johannes Dreyer (1500-1544) - Die Hervormer van Herford', HTS Teologiese Studies/Theological Studies 73(1), a3211. https://doi.org/10.4102/hts. v73i1.3211

Goeters, G.F.J., 1971, Die Akten der Synode der Niederländischen Kirchen zu Emden vom 4-13. Oktober 1571, Neukirchener Verlag, Neukirchen-Vluyn.

Jürgens, H.P., 1999, Johannes a Lasco. Ein Leben in Büchern und Briefen, Foedus, Wuppertal.

Knappert, L., 1924, Het ontstaan en de vestiging van het Protestantisme in de Nederlande, A. Oosthoek, Utrecht.
Moock, S.J.M., 1846, Nieuw Fransch-Nederduitsch en Nederduitsch-Fransch Woordenboek, C.A. Thieme, Arnhem.

Nel, P.J., 2019, 'A theological-historical investigation of the reception of the Church Order of Dort (1619) and the General Regulation (1816) in the church orders of reformed churches in South Africa', MTh dissertation, University of the Free State, Bloemfontein.

Pont, A.D., 1981, Die historiese agtergronde van ons kerklike reg, deel 1, HAUM, Pretoria.

Pont, A.D., 1991, Die historiese agtergronde van ons kerklike reg, deel 2, Kital, Pretoria.

Pont, A.D., 1994, 'Algemene Kerkgeskiedenis. 'n Inleiding tot die Nederlandse Kerkgeskiedenis: Van die beginjare tot 1795', Hervormde Teologiese Studies suppl. ser. 6.

Schilling, H. \& Schreiber, K.-D., 1989, Die Kirchenratsproltokolle der Reformierten gemeinde Emden 1557-1620 Teil 1, 2 \& 3: 1557-1547, Böhlau Verlag, Köln, Wien.

Voss, H-D., 2012, Menso Alting - eine Kurzbiographie, in K-D. Voss \& W. Jahn (Hrsg.) Menso Alting und seine Zeit. Glaubenstreit, Freiheit, Bürgerstolz, pp. 13-79, Irensee Verlag, Oldenburg. 